Volume 11, Issue 12, December 2020, pp. 825-834. Article ID: IJM $11 \_12076$

Available online at http://iaeme.com/Home/issue/IJM?Volume $=11 \&$ Issue $=12$

Journal Impact Factor (2020): 10.1471 (Calculated by GISI) www.jifactor.com

ISSN Print: 0976-6502 and ISSN Online: 0976-6510

DOI: 10.34218/IJM.11.12.2020.076

\title{
AN EMPIRICAL STUDY TO ANALYSE CUSTOMER SATISFACTION AND EXPERIENCE IN AN INDIAN HOSPITALITY CHAIN OF LEASED AND FRANCHISED HOTELS, HOMES AND LIVING SPACES IN INDORE CITY
}

\author{
Dr. Niraj Chimote \\ Associate Professor, ICFAI Business School (IBS) Hyderabad, Telangana, India \\ Shruti Jain \\ Student of MBA: 2019-21 Batch, IBS Hyderabad, Telangana, India
}

\begin{abstract}
Customer satisfaction is a critical concept for customer success professionals to understand and live by, and it's actually about more than a money-back guarantee. In this post, we'll start discussing customer satisfaction: what it is, and why your business needs to start measuring.
\end{abstract}

Key words: Supply Chain Management, Backhoe Loader, Buying Process, Consumer Buying Behavior, Customer Satisfaction, Hotels, Hospital

Cite this Article: Niraj Chimote and Shruti Jain, An Empirical Study to Analyse Customer Satisfaction and Experience in an Indian Hospitality Chain of Leased and Franchised Hotels, Homes and Living Spaces in Indore City, International Journal of Management, 11(12), 2020, pp 825-834.

http://iaeme.com/Home/issue/IJM?Volume=11\&Issue=12

\section{INTRODUCTION}

\subsection{Customer Satisfaction and Experience}

Customer satisfaction is a critical concept for customer success professionals to understand and live by, and it's actually about more than a money-back guarantee. In this post, we'll start discussing customer satisfaction: what it is, and why your business needs to start measuring.

Philip Kotler defines customer satisfaction as a 'person's feeling of pleasure or disappointment, which resulted from comparing a product's perceived performance or outcome against his/her expectations'. Although Kotler uses abstract terms like pleasure and disappointment, the definition is by no means ambiguous. 


\section{Customer satisfaction $=$ F (Perceived performance, Buyer's expectations)}

Customer experience is the sum of emotions felt by customers generated both at a specific point in time and cumulatively through their interactions with the employees, channels, services or products of a provider. Customer Experience can be delivered only if your products and services meet your customers' expectations.

\section{LITERATURE REVIEW}

Rao \& Sahu (2013) in their study entitled "Impact of Service Quality on Customer Satisfaction in Hotel Industry" shows that customer satisfaction means that how the customer perceives service delivery. Customer satisfaction is a function of service performance relative to customer expectation. For this reason, it is important to understand how customer expectation is formed to identify the factors of service satisfaction in the hotel industry. As different customers have different expectations, based on their knowledge of a product or service. This can be implied that a customer may estimate what the service performance will be or may think what the performance ought to be. If the service performance meets or exceeds customers ${ }^{\text {ee }}$ expectation, the customers will be satisfied. Previous research explored customer satisfaction regarding the service quality of all areas in the hotel so that the hotel can assess customer perception. This study identified five factors of service quality by focusing on the front office staff only and explored the customers' expectations and perception levels of these services. The results of this quantitative assessment of service quality might provide some insights into how customers rate the service quality and assessed customers' satisfaction. And the five factors which were included in this research was Tangibility, Reliability, Responsiveness, Assurance and Empathy.

Bhavani \& Pawar (2013) in their study entitled "Customer's Expectations of Hospitality Services - A Study on Five Star Hotels in Hyderabad City" showed that this paper analyses the customer's expectations and their satisfaction levels about services offered by five-star hotels in Hyderabad city. A structured questionnaire has been used to obtain feedback from the 150 customers from five-star hotels based on convenience sample method. Statistical tools such as Chi-square and Pearson's correlation were employed to validate the results. Findings of the study are (i) there is a relationship between expectations of the customers and the services provided by the star hotels (ii) there is a relationship between customers satisfaction about the price charged by the star hotels for the quality of services offered. It is also proved that there is a positive correlation among the above-presented parameters. It is suggested that the application of customer relationship management (CRM) is the need of the hour to fulfil the expectations of customer services.

Ozer \& Basgoze (2014), in their study entitled "Does the Consequences of overall service quality and transaction-specific service quality differ?" stated that the goal of the present paper is to propose an integrated model that assessing the relative impact of "overall service quality" and "transaction-specific service quality" on customer (dis)satisfaction, complaint behaviour, word of mouth and repurchase intention independently. A model is proposed that integrates the overall service quality and transaction-specific service quality under a single framework. The paper uses confirmatory factor analysis and structural equation modelling to analyse and confirm the conceptual model proposed in this research. According to findings, consumers feel dissatisfaction and complaint if they perceive transaction-specific service quality low. However, overall service quality significantly affects loyalty and word of mouth behaviour of hotel visitors.

Anawade P.A, Dr.Shilpak Bendale (2016) in their research paper "Recent trends in the Hotel industry and its impact on individual spending". The researcher reviewed the impact of spending on hoteling by the individual. The rural area was considered for review and the 
researcher tried to focus on the changes in spending pattern due to the recent trends in the Hotel Industry in rural areas. The research was based on primary data and was descriptive and concluded that trends in perception of hoteling and spending pattern of individual were changing continuously day by day and many 31 changes were derived as per the financial condition of the individual. The conclusions will facilitate the Hospitality industry to chalk out more effective strategies of marketing.

Jana \& Chandra (2016), customer satisfaction has become an important aspect of the hotel industry. Unlike other industries, the hotel industry prospers due to customers' retention. It is only through customer satisfaction that a hotel can retain its customers. Basically, customers' loyalty is dependent on the quality of the services that they get in a hotel. Moreover, the hospitality industry has experienced the entrance of many investors who are willing to meet all the needs of their customers. Therefore, if customers are not satisfied with the services, they receive in one hotel, they will look for better services elsewhere.

\section{RESEARCH GAPS}

Service Quality: There is a significant difference between customer perceived service quality standards and customer expectations of service quality. Hospitality Sector's services may take some more time for it to become fully reliable. It has a strong significance related to customer satisfaction and repeat business from the same customers. This study aims to analyse customer satisfaction towards service quality.

Perception-Expectations: A perception is always having a lesser rating than the expectations.

Research Objective: To explore the factors affecting customer experience in an Indian Hospitality Chain of leased and franchised hotels, homes and living spaces in Indore city.

Research Design (Malhotra \& Dash, 2009): Descriptive Research Design is used in the study

\section{SPECIFICATION OF THE MEASUREMENT AND SCALING PROCEDURES}

The study consists of the usage of Likert's scale for measuring the variables. Some of the variables like friendly, housekeeping, check-in-process, and services consist of a series of statements where the respondents have to provide answers in the form of extremely, quiet, moderately and not at all well. So, the respondent needed to select a numerical score (like 1 or 2 or 3 or 4 or 5) for each statement to indicate the degree of agreement or otherwise. Each score has to be finally added up to measure the respondent's attitude. Thus, a Likert's scale has been used to measure them.

\subsection{Survey}

The time period of the study was from February 2020 to May 2020. It was conducted in Indore city through a Standardized Questionnaire Survey that was filled by customers who have utilised the hotel services as per the data given by the management of the hotel chain. An Indian hospitality chain of leased and franchised hotels, homes and living spaces was chosen for conducting this study. The data of 10 different hotels related to the same hotel chain was provided by their head office out of which the customers who had utilized the hotel service were chosen from the sampling frame randomly. A prior permission was taken from the customers for getting their responses. The responses of the customers, who granted permission for the data collection, have been included in the survey. Among the survey participants, 45 out of 75 respondents were below 40 years of age and 39 out of 75 
respondents were Males. The names of the hotels and respondents cannot be mentioned as Authorization letter/NOC to use their names has not been provided by the hotel management and the survey participants.

\subsection{Description of the Questionnaire}

The questionnaire is provided in Appendix 1. It has been developed on the basis of the feedback forms designed by the management of the hotel chain by considering customer service-related aspects.

The feedback forms of the hotel chain have been developed by them after extensive and thorough study of Customer service aspects in the hospitality sector and with respect to its competitors.

- Being Friendly

- Housekeeping

- Being Professional

- Being Helpful

- Being Polite

- Being Well-equipped

- Quickness of check-in Process

- Being Comfortable

- Being Clean

- Being Quick

- Getting Affordable Stay

- Delicious Food

- Likely to Stay Again

- Being Convenient

- Getting Affordable breakfast

\subsection{Reliability Analysis}

These coefficients are expected to indicate reliability as they ought to meet the minimum acceptable level of 0.6 (Hair et al., 2007).

\subsection{Factor Analysis}

It is a set of process in which the evident responses of people on a group of variables are represented as functions of a small number of latent variables referred to as factors. The present study contains a large number of variables that would make the analysis and interpretation of the problem difficult. Factor analysis helps to reduce the number of variables to be analysed into a few factors that may summarize the available data. It is needed to identify the underlying dimensions that would explain the correlations among a set of variables. Bartlett's test of sphericity has been used to test the null hypothesis that the variables are uncorrelated in the population through a Chi-square statistic. The factor analysis would be called appropriate if the null hypothesis is rejected. Along with that, the KaiserMeyer-Olkin (KMO) measure of sampling adequacy also has been tested through an index. 
Generally, a value greater than 0.5 is desirable for concluding that factor analysis is appropriate.

Exclusion of Variables: However, two variables from the questionnaire have been left out of the factor analysis - 'Likely to stay again' and 'quickness of check-in process'. The variable namely Likely to stay again' is not relevant for factor analysis, as it is not a variable that influences customer satisfaction, but is an outcome of customer satisfaction. 'Quickness of check-in process' was left out as there was another question on how quickly the hotel staff responded to requests.

\subsection{Analysis of data}

The minimum number of responses required should be five times the number of variables (Malhotra \& Dash, 2009). Hence, the break-up of the minimum number of responses has been given in Table 1 as follows:

Table 1

\begin{tabular}{|l|c|c|}
\hline \multicolumn{1}{|c|}{ Minimum responses required for Factor Analysis } \\
\hline & $\begin{array}{c}\text { Number of metric } \\
\text { variables }\end{array}$ & $\begin{array}{c}\text { Minimum number of responses } \\
\text { required (Number of Variables*5) } \\
\text { (Malhotra \& Dash,2009) }\end{array}$ \\
\hline $\begin{array}{l}\text { Customer Satisfaction } \\
\text { \& Expectation }\end{array}$ & 15 & 75 \\
\hline Total & 15 & 75 \\
\hline
\end{tabular}

\subsection{Reliability Analysis}

The survey questionnaire had to be tested for its reliability. An analysis was conducted for checking the reliability of the questionnaire and the results were obtained.

Table 2

\begin{tabular}{|c|c|}
\hline \multicolumn{2}{|c|}{ Cronbach's alpha score } \\
\hline \multicolumn{2}{|c|}{ Reliability Statistics } \\
\hline Cronbach's Alpha & N of Items \\
\hline .906 & 15 \\
\hline
\end{tabular}

Table 3

\begin{tabular}{|l|l|l|}
\hline \multicolumn{2}{|c|}{ KMO and Bartlett's Test } \\
\hline $\begin{array}{l}\text { Kaiser-Meyer-Olkin Measure of Sampling } \\
\text { Adequacy. }\end{array}$ & .881 \\
\hline Bartlett's Test of Sphericity & Approx. Chi-Square & 569.287 \\
\hline & df & 105 \\
\cline { 2 - 3 } & Sig. & .000 \\
\hline
\end{tabular}


Niraj Chimote and Shruti Jain

Table 4

\begin{tabular}{|c|c|c|c|c|c|c|}
\hline \multicolumn{7}{|c|}{ Total Variance Explained } \\
\hline Component & \multicolumn{7}{|c|}{$\begin{array}{c}\text { Rotation Sums of Squared } \\
\text { Loadings }\end{array}$} \\
\cline { 2 - 7 } & Total Eigen values & $\begin{array}{c}\text { \% of } \\
\text { Variance }\end{array}$ & $\begin{array}{c}\text { Cumulative } \\
\text { \% }\end{array}$ & Total & $\begin{array}{c}\text { \% of } \\
\text { Variance }\end{array}$ & $\begin{array}{c}\text { Cumulative } \\
\text { \% }\end{array}$ \\
\hline 1 & 6.815 & 45.436 & 45.436 & 3.650 & 24.332 & 24.332 \\
\hline 2 & 1.238 & 8.252 & 53.687 & 3.015 & 20.097 & 44.429 \\
\hline 3 & 1.169 & 7.792 & 61.480 & 2.558 & 17.051 & 61.480 \\
\hline 4 & .966 & 6.441 & 67.921 & & & \\
\hline 5 & .754 & 5.024 & 72.945 & & & \\
\hline 6 & .647 & 4.316 & 77.261 & & & \\
\hline 7 & .601 & 4.006 & 81.267 & & & \\
\hline 8 & .537 & 3.583 & 84.850 & & & \\
\hline 9 & .441 & 2.940 & 87.790 & & & \\
\hline 10 & .405 & 2.698 & 90.489 & & & \\
\hline 11 & .385 & 2.569 & 93.057 & & & \\
\hline 12 & .336 & 2.239 & 95.297 & & & \\
\hline 13 & .301 & 2.004 & 97.301 & & & \\
\hline
\end{tabular}

Table 5

\begin{tabular}{|l|c|c|c|}
\hline \multicolumn{4}{|c|}{ Rotated Component Matrix } \\
\cline { 2 - 4 } \multicolumn{1}{|c|}{ Name of Variables } & $\mathbf{1}$ & $\mathbf{2}$ & $\mathbf{3}$ \\
\hline Friendly & .646 & .160 & .311 \\
\hline Housekeeping & .273 & .721 & .325 \\
\hline Professional & .635 & .326 & .340 \\
\hline Helpful & .683 & .176 & .422 \\
\hline Polite & .684 & .143 & .431 \\
\hline Well-equipped & .389 & .338 & .576 \\
\hline Comfortable & .173 & .869 & .114 \\
\hline Clean & .339 & .733 & .117 \\
\hline Quickly & .236 & .512 & .478 \\
\hline Affordable Stay & .603 & .130 & -.013 \\
\hline Delicious Breakfast & .042 & .418 & .628 \\
\hline Convenient & .641 & .269 & .237 \\
\hline Affordable Breakfast & .191 & .021 & .818 \\
\hline
\end{tabular}

Table 6

\begin{tabular}{|c|c|c|c|}
\hline \multicolumn{4}{|c|}{ Summary Table of Factors } \\
\hline \multicolumn{4}{|c|}{ Component Transformation Matrix } \\
\hline Component & $\begin{array}{c}\text { Factor } 1 \\
\text { (Service Interaction } \\
\text { Attribution) }\end{array}$ & $\begin{array}{c}\text { Factor } 2 \\
\text { (Maintenance and Good } \\
\text { Atmosphere) }\end{array}$ & $\begin{array}{c}\text { Factor } 3 \\
\text { (Food \& Beverages) }\end{array}$ \\
\hline 1 & Being Friendly. & & \\
\hline 2 & & Housekeeping & \\
\hline 3 & Being Professional & & \\
\hline 4 & Being Helpful & & \\
\hline 5 & Being Polite & & \\
\hline 6 & & & Being Well-equipped \\
\hline 7 & & Being Comfortable & \\
\hline 8 & & Being Clean & \\
\hline 9 & & Being Quick & \\
\hline 10 & Affordable Stay & & \\
\hline 11 & & & Delicious Food \\
\hline 12 & Convenient service & & \\
\hline 13 & & & Affordable Breakfast \\
\hline
\end{tabular}


An Empirical Study to Analyse Customer Satisfaction and Experience in an Indian Hospitality Chain of Leased and Franchised Hotels, Homes and Living Spaces in Indore City

Factor 1: It includes the variables that have the highest loading on factor 1 after rotation. The above factor has been named as Service Interaction Attributes as all the variables indicate the interaction between the customers with staff.

Factor 2: It includes the variables that have the highest loading on factor 2 after rotation. The above variables indicate Maintenance and Good atmosphere is done on the part of hotels.

Factor 3: It includes the variables that have the highest loading on factor 3 after rotation. The above variables indicate attributes related to food and beverages as these variables give the customer to think before booking.

\section{CONCLUSION}

The factors explored in this analysis are Service Interaction Attributes, Maintenance and Good atmosphere and food and beverages. The findings ensure that through maintaining important factors and quality services, Hospitality Sector service vendors can easily retain customers.

\subsection{Managerial Implications}

- The results have helped to understand the determining factors of customer's decision making in the Hospitality Sector.

- Personnel in the customer care service section of the financial institution should be friendly and create a friendly relationship with their customers.

- There should be seminars for members of staff on the need to improve their relationship with customers, and also on the importance of customer satisfaction as a vital tool for creating and improving customer loyalty.

- The environment should be conducive and enabling. More so, it should be attractive and decent.

\subsection{Limitations}

The results obtained in this study are subject to some limitations as mentioned below:

- This is not a comparative study.

- Since the responses were recorded on a Likert scale, there was no available means to verify the accuracy of the data collected. Thus, it was assumed that the data was errorfree.

- The ability to generalize the results may be affected by the size and composition of the sample.

- The analyses were limited to only customers.

- Results may differ if different items were selected or different scales are used. Therefore, results cannot be generalized for other service contexts. 


\section{APPENDIX QUESTIONNAIRE}

Name:

Phone Number:

1) Overall, how friendly was the Hotel staff?

a) Extremely friendly

b) Quite friendly

c) Moderately friendly

d) Somewhat friendly

e) Not at all friendly

2) How well did the housekeeping staff clean your room?

a) Extremely well

b) Quite well

c) Moderately well

d) Somewhat well

e) Not at all well

3) Overall, how professional was the Hotel staffs?

a) Extremely professional

b) Quite professional

c) Moderately professional

d) Somewhat professional

e) Not at all professional

4) How helpful was the concierge throughout your stay?

a) Extremely helpful

b) Quite helpful

c) Moderately helpful

d) Somewhat helpful

e) Not at all helpful

5) Overall, how polite were the Hotel staffs?

a) Extremely polite

b) Quite polite

c) Moderately polite

d) Somewhat polite

e) Not at all polite

6) Overall, how well-equipped was your room?

a) Extremely well-equipped

b) Quite well-equipped

c) Moderately well-equipped

d) Somewhat well-equipped

e) Not at all well-equipped

7) How quick was the check-in process?

a) Extremely quick

b) Quite quick 
An Empirical Study to Analyse Customer Satisfaction and Experience in an Indian Hospitality Chain of Leased and Franchised Hotels, Homes and Living Spaces in Indore City

$\begin{array}{ll}\text { c) } & \text { Moderately quick } \\ \text { d) } & \text { Somewhat quick } \\ \text { e) } & \text { Not at all quick }\end{array}$

8) How comfortable were your bed linens?

a) Extremely comfortable

b) Quite comfortable

c) Moderately comfortable

d) Somewhat comfortable

e) Not at all comfortable

9) How clean was your room upon arrival?

a) Extremely clean

b) Quite clean

c) Moderately clean

d) Somewhat clean

e) Not at all clean

10) Overall, how quickly did the Hotel staff respond to your requests?
a) Extremely quickly
b) Quite quickly
c) Moderately quickly
d) Somewhat quickly
e) Not at all quickly
f) Not applicable

11) How affordable was your stay at our hotel?

a) Extremely affordable

b) Quite affordable

c) Moderately affordable

d) Somewhat affordable

e) Not at all affordable

12) How delicious was the hotel breakfast service?
a) Extremely delicious
b) Quite delicious
c) Moderately delicious
d) Somewhat delicious
e) Not at all delicious

13) How likely are you to stay at our hotel again?

a) Extremely likely

b) Quite likely

c) Moderately likely

d) Somewhat likely

e) Not at all likely

14) How convenient were the hours of the foodservice options at our hotel?

a) Extremely convenient

b) Quite convenient 
c) Moderately convenient

d) Somewhat convenient

e) Not at all convenient

15) How affordable was the hotel breakfast service?

a) Extremely affordable

b) Quite affordable

c) Moderately affordable

d) Somewhat affordable

e) Not at all affordable

\section{REFERENCES}

[1] Philip Kotler (2018). Marketing Management- 15th ed. Pearson Education India.

[2] Malhotra, N. and Dash, S. (2009). Marketing Research- An Applied Orientation. 5th ed. Pearsoln Education India.

[3] Rao \& Sahu (2013) - "Impact of Service Quality on Customer Satisfaction in Hotel Industry" IOSR Journal Of Humanities And Social Science (IOSR-JHSS) Volume 18, Issue 5 (Nov. - Dec. 2013)

[4] Bhavani \& Pawar (2013) - “Customer's Expectations of Hospitality Services - A Study on Five Star Hotels in Hyderabad City" Journal of Management and Science, Vol.3. No 4, December 2013

[5] Ozer \& Basgoze (2014) — "Does the Consequences of overall service quality and transactionspecific service quality differ?" International Journal of Business and Management Review, Issue: 2

[6] Anawade P. A, Dr. Shilpak Bendale (2016) — "Recent Trends in the Hotel industry and its impact on individual spending" International Conference on Global Trends in Engineering, Technology and Management (ICGTETM-2016) http://www.ijettjournal.org

[7] Jana, A., \& Chandra, B. (2016), - "Mediating Role of Customer Satisfaction in the MidMarket Hotels: An Empirical Analysis" Indian Journal of Science and Technology http://dx.doi.org/10.17485/ijst/2016/v9i1/81973

[8] A study of customer perception and consumer buying behaviour of hospitality sector with special reference to Pune city, International Journal of Management, Technology and Engineering, India http://ijamtes.org/gallery/209-jan19.pdf 